\title{
Inflationary Expectations and Monetary Adjustment in Nigeria: $1960-1978$
}

\author{
M. A. Shahi and I. H. SHEIKH*
}

\begin{abstract}
Short-run money demand functions are estimated and elasticities of price expectations and real cash balance adjustment are determined. By examining the hypothesis that inflation in Nigeria is self-generating, the study concludes that explanations for the rise in price level should be sought in factors other than money supply alone.
\end{abstract}

\section{INTRODUCTION}

The objective of this paper is to examine the short-run demand for money in a situation of inflationary expectations and to compare the results with those of a few other similar studies for various countries. It is also intended to determine the elasticity of price expectations and that of real cash balance adjustment, and to find out whether inflation in Nigeria is self-generating or not.

The period under consideration has been characterised by certain major developments both on the political and on the economic fronts with consequent effects on money supply and the price level. On the political front, the Civil $\mathrm{War}^{1}$ during its course brought about a considerable increase in the stock of money. Thus the money stock during this period continued to grow at about 14.0 percent per annum. The subsequent Oil Boom, ${ }^{2}$ starting in 1970 and leading to an increased monetisation of government expenditures, also witnessed an increase in the general price level at 17.0 percent per annum over the period 1970-76. Further, the implemen-

*The authors are currently on the faculty of the Department of Economics, Ahmadu Bello University, Zaria (Nigeria). They would like to thank their colleague, Dr. N. Khawaja, for his helpful comments and suggestions, especially in connection with the econometric aspects of this paper. However, the authors alone are responsible for any remaining errors.

${ }^{1}$ Following the secession of the then Eastern Region on May 30, 1967, the Federal Military Government had to take military action. This conflict ultimately ended with the surrender of the secessionist regime in January 1970, and has come to be known as the Civil War. See $[2$, p. 12] and $[3$, p. 9].

${ }^{2}$ The Oil Boom effectively began when towards the end of 1970 following the successful negotiation of increases in posted prices by Libya, the oil-producing companies increased the posted prices of Nigerian crude oil by 25 cents per barrel effective September 1,1970 . See' $[3$, p. 26] . 
tation of various wage awards both in the public and in the private sectors following the recommendations of the Udoji and Williams' pay commissions, ${ }^{3}$ had an enormous impact on the stock of money which increased at the rate of 52.0 percent per annum during the period $1974-78$. The price level was also affected considerably by the various developments and increased at a rate of 28.0 percent per annum during the period 1974-78. These price and other developments are summarised in Table 1.

Table 1

Rates of Change of Prices and of Nominal Money Stock ${ }^{1}$

(Percent)

\begin{tabular}{|c|c|c|c|c|}
\hline \multicolumn{3}{|c|}{ Period (Era) } & Prices $^{2}$ & Money Stock ${ }^{3}$ \\
\hline 1960 & I -1967 I & I (Pre-Civil War) & 0.9 & 1.7 \\
\hline 1967 & II -1970 I & I $\quad$ (Civil War) & 1.7 & 4.5 \\
\hline 1970 & II -1974 II & I (Pre-Udoji) & 2.4 & 4.5 \\
\hline 1974 & III -1978 I & I (Post-Udoji) & 6.5 & 13.0 \\
\hline 1970 & II -1978 I & I (Post-Civil War) & 4.0 & 8.0 \\
\hline 1960 & I -1978 I & I (All Years) & 2.3 & 4.6 \\
\hline
\end{tabular}

Source: Central Bank of Nigeria. Economic and Financial Review. (Various Issues)

${ }_{2}^{1}$ Quarterly Averages.

${ }^{2}$ Consumer Price Index (Base $1960=100.0$ ); this index is also used as a deflator

in this paper.

${ }^{3}$ Money Stock as defined by the Central Bank of Nigeria (i.e. the conventional definition of money).

It may be noted that there is found a sort of direct and approximately proportional relationship between the growth rates in the stock of money and the general price level. This relationship is more obvious for the post-Udoji period, where the data depict a strictly 2:1 relationship between the stock of money and the general price level. This, other things being equal, may point out the applicability of the quantity theory of money with its obvious policy implications for control of inflation in Nigeria. ${ }^{4}$ Further, it may also help us determine whether inflation in this country is self-generating or not. See [7, pp.474-480] and [1]. In this

${ }^{3}$ The recommendations of the Public Sector Review Commission (popularly known as the Udoji Commission after its chairman Chief Jerome Udoji) and those of the subsequent Williams' Commission that were accepted by the Federal Government were implemented with effect from April 1, 1974, and the salary structure in the public sector was revised upwards considerably. Similar increases in wages were granted by the private sector based on the guidelines laid down by the Udoji Commission for public sector. See [11].

${ }^{4}$ The neo-quantity theorists, whose leading exponent is Milton Friedman, regard the increase in the general price level (or at least a major part of it) due to the lack of will on the part of the monetary authorities to control the stock of money. On this, see [15, chapter 15]. connection, we specify our model below and test this with the use of quarterly data for the sub-periods as well as for the entire observation period. The results obtained from this exercise are listed in our section on Empirical Results, and our conclusions are presented under Concluding Remarks.

\section{SPECIFICATION OF THE MODEL}

Following Friedman [4], it may be suggested that the demand for money is independent of nominal units, and hence may conveniently be written as:

$$
\mathrm{M} / \mathrm{P}=\mathrm{f}(\mathrm{Y}, \mathrm{W}, \mathrm{r}, \dot{\mathrm{P}})
$$

where $\mathrm{M}$ denotes the nominal quantity of money, which we define as currency with the public and demand deposits of the commercial banking system, $\mathrm{P}$ denotes the general price level, $\mathrm{Y}$ is measured or permanent income and $\mathrm{W}$ stands for wealth. Further, $r$ represents a vector of interest rates and $\dot{P}$ the rate of change of the general price level.

With the specification of the function in the above form, one is faced with two problems: that of identification and that of data availability. The first problem is quite common to all single-equation demand functions. In order to overcome this, one can make a convenient assumption that the nominal stock of money is given ex. ogenously. This may not be unrealistic in the Nigerian context, for monetary expansion during the major part of our observation period has been the result of a considerable increase in government expenditures. ${ }^{5}$ The limitations posed by the non-availability of data constitute a more serious problem for estimation of the above equation. In the first place, quarterly data either on income or on the wealth variables do not exist. Hence the omission of these variables may lead to a specification bias in the ultimate results. However, during the observation period the average percentage change in real national income was considerably below the average percentage change in the general price level. Thus, with such a substantial change in the general price level, real income and wealth may not reveal any significant influence in the determination of real cash balance [7, p.475]. Secondly, no data are available on long-term government bond yields whereas quarterly data are easily available for various other rates of interest. This may not cause any problem for we can employ other short-term rates in the estimation, as our function is dynamic in character. But the available rates are tied up to the rediscount rate of the Central Bank of Nigeria and hardly show any variation. ${ }^{6}$ Moreover, the Central Bank's rediscount rate itself has remained fairly constant over considerable periods.

5 Overall government expenditure as a percentage of national income increased from 10 percent in 1960 to 17 percent in 1974 and in absolute terms from $\mathbb{N} 227$ million to $\mathbb{N} 1543$ million. See [9].

${ }^{6}$ The general level of interest rates in the country is tied up with Central Bank of Nigeria's rediscount rate by virtue of Section 14 of the Banking Decree No. 1 of 1969. On this and the structure of the interest rates in general, see [14]. 
In addition, where this rediscount rate or other interest rates have been used in estimating the demand for money, no significant relationship has been found to exist between the demand for real cash balances and the rate/rates of interest. ${ }^{7}$ Thus our estimation problems may be considerably simplified by dropping both the income/wealth and the interest rate/rates variables. With this modification and with the variables in logarithms, the specification to be tested may be written as:

$$
\mathrm{M}_{\mathrm{t}}^{*}=\mathrm{B}_{\mathrm{o}}+\mathrm{B}_{1} \mathrm{P}_{\mathrm{t}}^{*}+\mathrm{e}_{\mathrm{t}}
$$

where $\mathrm{M}^{*}$ denotes the desired long-run stock of real cash balances, and $\mathrm{P}^{*}$ denotes the expected rate of change of prices. The subscript $t$ denotes time and $e$, the error term. Since in the equation the desired stock of cash balances depends upon the expected change in the general price level, and since neither of these variables is observable, we need to relate these to observable values if the equation is to be estimated. Hence, it is essential to specify the 'expectations and adjustment' mechanisms.

With the assumption that, in any given period, the actual value of cash balances, M, may not adjust itself completely to the desired level $\mathbf{M}^{*}$ but only partially approach such a desired level, we may specify the adjustment mechanism as [12,pp. 214-216] :

$$
\mathrm{M}_{\mathrm{t}}=\mathrm{M}_{\mathrm{t}-1}+\theta\left(\mathrm{M}_{\mathrm{t}}^{*}-\mathrm{M}_{\mathrm{t}-1}\right) \quad 0 \leqslant \theta \leqslant 1 \ldots \quad \ldots
$$

Further assuming that inflationary expectations are governed by an adaptive process [8, pp. 313-315], and the expected price level thus depends upon its previous expected value and upon the fractional difference between the actual price level $\mathrm{P}_{t}$ and its previous expected value $\mathrm{P}_{t-1}^{*}$, we may write

$$
\mathrm{P}_{\mathrm{t}}^{*}=\mathrm{P}_{\mathrm{t}-1}^{*}+\delta\left(\mathrm{P}_{\mathrm{t}}-\mathrm{P}_{\mathrm{t}-1}^{*}\right) 0 \leqslant \delta \leqslant 1 \quad \ldots \quad \ldots
$$

Substituting equation (2) into equation (3), we obtain

$$
\mathrm{M}_{\mathrm{t}}=\theta \mathrm{B}_{\mathrm{o}}+\theta \mathrm{B}_{1} \mathrm{P}_{\mathrm{t}}^{*}+(1-\theta) \mathrm{M}_{\mathrm{t}-1}+\theta \mathrm{e}_{\mathrm{t}} \cdots
$$

Further, by successive substitution for $\mathrm{P}^{*}$ from equation (4) into the above we obtain the following reduced form:

$\mathrm{M}_{\mathrm{t}}=\delta \theta \mathrm{B}_{\mathrm{o}}+\delta \theta \mathrm{B}_{1} \mathrm{P}_{\mathrm{t}}+(1-\delta)+(1-\theta) \mathrm{M}_{\mathrm{t}-1}-(1-\delta)(1-\theta) \mathrm{M}_{\mathrm{t}-2}+\mathrm{U}_{\mathrm{t}}$

The above equation contains all the variables in their observable form and hence is suitable for estimating purposes. The parameters $\delta$ and $\theta$ further denote the coefficient of expectations and the coefficient of adjustment respectively. However, we note that the error term $U_{t}=\theta\left[e_{t}-(1-\delta) e_{t-1}\right]$ is a composite term, and is likely to be autocorrelated as well. For convenience, it is generally assumed that the error term is of the first order autoregressive type. But it is quite likely that the term may be more of an auteregressive moving-average type and this can be determined only

${ }^{7}$ For a comparative study for the West African countries including Nigeria, and using both static and dynamic specifications, see [13]. empirically [12, pp. 452-471]. Since this exercise is not going to add significantly to our conclusions, we do not examine the error term further.

It may be noted that in equation (6) the parameters $\delta$ and $\theta$ enter symmetrically and that the equation itself is overidentified. Further, where $\theta=1$, the equation becomes an adjustment model, and when $\delta=1$, the equation becomes an expectations model. Since in our case both the adjustment and the expectations processes are operative, in order to distinguish other parameters, it is necessary to place some $a$ priori restrictions upon $\delta$ and $\theta$, which we have already done by constraining their values to be between zero and unity. Moreover, the equation itself being a segment of a larger model in which the lagged $\mathrm{M}$ terms are endogenously determined, estimation of the same equation with the observed values of lagged $\mathrm{M}$ is likely to give biased estimates of the parameters - a simultaneous-equation bias being inherent in the parameters. To avoid this problem, we utilize a two-stage estimation method. Thus, we first obtain the estimated value of lagged $\mathbf{M}$ as functions of lagged $P$, and substitute these estimated values for $M$ in equation (6). The estimation technique used, therefore, is the two-stage least-squares constrained non-linear regression technique [5; pp. 186-195], which provides us with our estimates of the unique structural parameters.

\section{EMPIRICAL RESULTS}

The estimates from equation (6) for various sub-periods and for the observation period as a whole are shown in Table 2. The sub-periods are classified on the basis of the presence/absence of certain major political and economic events. ${ }^{8}$ Judging in terms of the standard criteria, viz. the a priori sign and significance of the coefficient of the price variable, the results shown are generally satisfactory.

The coefficient of price expectations, $\delta$, represents the speed with which the expectations regarding the rate of change of prices are revised, and its inverse, the average length of time, by which such expectations of price changes lag behind the actual price changes. The adjustment elasticity, $\theta$, represents the speed with which . the actual real cash balances adjust themselves to their desired long-run level, and its inverse depicts the average length of time by which such desired real cash balances lag behind the actual real cash balances. On the other hand, the coefficient $\mathbf{B}_{1}$ represents the elasticity of desired quantity of real cash balances with respect to the expected rate of change of prices.

The average lags, represented by the inverse of $\delta$ and $\theta$, range from about four to approximately eight months. Moreover, the period with the largest rate of change of prices, i.e. 1974 (III) - 1978 (I), has relatively larger values for both $\delta$ and $\theta$, which means that the average lags represented by the inverse of $\delta$ and $\theta$ are smaller in an inflationary situation. Thus, our results are in line with those

${ }^{8}$ Breakdown of the sample period as given in Table 1 of the text. 
obtained by Cagan [1, p. 43], Hynes [6, pp. 285-293], Hu [5, p. 194] and Koot [7, p. 479] for similar other studies. For periods of moderate inflation, ${ }^{9}$ say, where the rate of change of prices is around 10 percent per annum, the average lag works out to be around six months.

Table 2

Estimated Values of Regression Coefficients

\begin{tabular}{|c|c|c|c|c|c|c|}
\hline & Period & & $\mathrm{B}_{\mathrm{o}}$ & $\mathrm{B}_{1}$ & $\delta$ & $\theta$ \\
\hline 1960 & I - 1967 I & I & 3.855 & $\begin{array}{c}-1.8104 \\
(3.6984)\end{array}$ & $\begin{array}{c}0.3941 \\
(2.3121)\end{array}$ & $\begin{array}{c}0.3941 \\
(2.2145)\end{array}$ \\
\hline 1967 & II -1970 & I & 4.0167 & $\begin{array}{c}-1.3195 \\
(4.8951)\end{array}$ & $\begin{array}{c}0.4402 \\
(3.4213)\end{array}$ & $\begin{array}{c}0.4402 \\
(3.2896)\end{array}$ \\
\hline 1970 & II - 1974 II & II & 4.4781 & $\begin{array}{c}-1.9714 \\
(4.9715)\end{array}$ & $\begin{array}{c}0.4894 \\
(3.8019)\end{array}$ & $\begin{array}{c}0.4894 \\
(3.1415)\end{array}$ \\
\hline 1974 & III -1978 & I & 5.3144 & $\begin{array}{c}-1.7094 \\
(3.8519)\end{array}$ & $\begin{array}{c}0.67 \cdot 14 \\
(2.4121)\end{array}$ & $\begin{array}{c}0.6714 \\
(2.6034)\end{array}$ \\
\hline 1970 & II - 1978 & I & 7.0149 & $\begin{array}{c}-1.8562 \\
(2.9038)\end{array}$ & $\begin{array}{c}0.5216 \\
(2.4056)\end{array}$ & $\begin{array}{c}0.5216 \\
(2.1712)\end{array}$ \\
\hline 1960 & I - 1978 I & I & 4.2858 & $\begin{array}{c}-1.1815 \\
(2.4562)\end{array}$ & $\begin{array}{c}0.4975 \\
(2.0140)\end{array}$ & $\begin{array}{c}0.4975 \\
(2.1253)\end{array}$ \\
\hline
\end{tabular}

Note: "t" ratios appear in parentheses; all coefficients are significant at the 0.05 level.

The question whether inflation in the country is self-generating or not can be answered by examining the value of the product $\delta \mathrm{B}_{1}$, which measures the total reaction of the changes in the quantity of money on the price level. Where this product is less than unity, inflation is not self-generating. ${ }^{10}$ In such a situation, when the actual quantity of money increases at an increasing rate, the expected rate of change of prices lags behind the actual rate of change of prices. Where the product of $\delta \mathrm{B}_{1}$ is greater than unity, the inflation assumes a self-generating character. That our evidence favours the former conclusion is amply borne out by the results presented in Table 2 above, where, for all the periods shown, the product of $\delta B_{1}$ is less than unity.

\section{CONCLUDING REMARKS}

The model, estimated above, seems quite applicable to the short-run money demand function in Nigeria. The structural parameters further suggest the presence

${ }^{9}$ Relatively speaking 10 percent appears to be quite moderate in view of more than 20 percent in recent years. See Table 1.

10For the application of such a test, see [7, pp. 478-479]. of both expectations and adjustment lags and the adjustment of the actual to the desired level of real cash balances is:quite reflective of the inflationary situation in the country when judged in terms of the speed of such adjustment. Our results also are in line with those obtained by investigators for other countries under fairly similar situations. Finally, in spite of the several political and economic events in the country that tended to influence the quantity of money during the period under consideration, we do not find any indications of the self-generating character of inflation in Nigeria. Hence, the explanation for the rise in the price level should probably be sought in terms of factors other than increased supply of money alone [10]

\section{REFERENCES}

1. Cagan, P. "The Monetary Dynamics of Hyperinflation". In M. Friedman (ed.), Studies in the Quantity Theory of Money. Chicago: The University of Chicago Press. 1956.

2. Central Bank of Nigeria. Annual Report, 1967. Lagos. n.d.

3. Central Bank of Nigeria. Annual Report, 1970, Lagos. n.d.

4. Friedman, M. "The Quantitative Theory of Money - A Restatement". In M. Friedman (ed.), Studies in the Quantitative Theory of Money. Chicago: The University of Chicago Press. 1956.

5. Hu, Teh-wei. "Hyperinflation and the Dynamics of the Demand for Money in China, 1945-1949". The Journal of Political Economy. Vol. 79. February 1971.

6. Hynes, A. "The Demand for Money and Monetary Adjustments in Chile". Review of Economic Studies. Vol. 34. July 1967.

7. Koot, R. S. "Price Expectations and Monetary Adjustments in Uruguay". Social and Economic Studies. Vol. 21. December 1972.

8. Koutsoyiannis, A. Theory of Econometrics. 2nd Edition. 'London: MacMillan. 1977.

9. Nigeria. Annual Abstract of Statistics 1974. Lagos. n.d.

10. Nigeria. First Report of the Anti-Inflation Task Force. Lagos. 1976.

11. Nigeria. Report of the Public Sector Review Commission. Lagos. 1974

12. Pyndick, R. S., and D. L. Rubinfeld. Econometric Models and Economic Forecasts. New York: McGraw-Hill Book Company. 1976.

13. Shahi, M. A. "The Demand for Money: Evidence from Selected African Countries, 1960-74" Forthcoming in The Nigerian Journal of Business Management.

14. Shahi, M. A. "The Development of the Nigerian Money Market 1960-1976" Zaria (Nigeria): Ahmadu Bello University, Department of Economics. (Mimeographed)

15. Thorn, R. S. Introduction to Money and Banking. New York: Harper Row Publishers. 1976. 